\title{
Effect of the ammonia concentration on the performance of wetland microbial fuel cells
}

\author{
Li Wang ${ }^{1, *}$, Jiafeng $\mathrm{Fu}^{2}$, Wenlei Wang ${ }^{1}$, Yutong Song ${ }^{1}$, and Yan $\mathrm{Li}^{1}$ \\ ${ }^{1}$ Harbin Institute of Technology, School of Energy Science and Engineering, 150001, Harbin, China \\ ${ }^{2}$ Harbin Guanghan Gas Turbine Co., Ltd, 150070, Harbin, China
}

\begin{abstract}
This work explores the effect of the ammonia concentration on the wetland synthesis of microbial fuel cell (MFC) and on the production and the efficiency of sewage purification. Four ammonia concentrations from 1 to $30 \mathrm{mg} / \mathrm{L}$ have been selected. Under the fixed condition of a chemical oxygen demand (COD) concentration of $200 \mathrm{mg} / \mathrm{L}$, a constructed wetland microbial fuel cell (CW-MFC) could be built. The results show that by selecting the optimum ammonia concentration the production of the CWMFC could be promoted; a higher ammonia concentration $(>20 \mathrm{mg} / \mathrm{L})$ is found to inhibit the production activity of CW-MFC. In the optimum conditions, Cathode and anode thickness is $10 \mathrm{~cm}$, the ammonia concentration is $10 \mathrm{mg} / \mathrm{L}$, the COD concentration of $200 \mathrm{mg} / \mathrm{L}$, the maximum power density of the battery is $13.6 \mathrm{~W} / \mathrm{m}^{3}$, the corresponding current density is $148.6 \mathrm{~A} / \mathrm{m}^{3}$ and the battery internal resistance is $270 \Omega$. At the ammonia nitrogen concentration of $10 \mathrm{mg} / \mathrm{L}$, the removal rates of ammonia nitrogen and COD were up to $89.7 \%$ and $98.47 \%$ respectively. As the ammonia nitrogen concentration increased to $30 \mathrm{mg} / \mathrm{L}$, the ammonia nitrogen and COD removal rates decreased to $74.6 \%$ and $90.69 \%$ respectively. That is, when the ammonia nitrogen concentration is $10 \mathrm{mg} / \mathrm{L}, \mathrm{CW}-\mathrm{MFC}$ can exhibit the best performance.
\end{abstract}

\section{Introduction}

The wetland microbial fuel cell is a new type of water purification device, which combines an artificial wetland with a microbial fuel cell; the anaerobic oxidation of organic matter at the anode is promoted by a microbial metabolism under electrical bias [1-3]. When the plant root is located at the cathode region, the bio-cathode composite electrode material forms a plant-microbialelectrode material; the use of plant rhizosphere oxygen at the cathode provides for the reduction reaction of electron acceptors, and an oxidizing microenvironment is formed in the reduced matrix around the root system $[4,5]$. To reduce the operating costs there is an urgent requirement for developing improved cathodic aeration devices. At the same time, the use of plant composite bio-cathodes instead of precious metal cathodes as in the conventional CW-MFC, would allow to greatly reduce the electrode material costs, possibly improve the catalytic activity of the electrode and allow for the largescale production of CW-MFCs [6-8].

For the development of large-scale CW-MFC, the high cost of the infrastructure and the too low power generation are the two main problems; the cathode material plays a key role in these problems, because of its high cost and slow redox reaction. In order to overcome these bottlenecks, it is necessary to develop suitable cathode based on an easy preparation method, cheap and ensuring a high catalytic activity. Recently, it has been shown that aerobic biofilms are capable of efficiently catalyzing redox reactions [9], while ensuring low cost, self-regeneration of the catalyst, sustainability and good activity at neutral $\mathrm{pH}$; for these reasons, the study of biological cathodes has attracted a wide interest [10]. Compared with inorganic cathodes, the biocathode is promising in the CW-MFC application.

Many previous studies have shown that when the rhizosphere is located in the anode chamber of the CWMFC, the plant root exudates (sugar, organic acid, polymeric carbohydrates, dead cell material, etc.) can be used as organic matter to generate electricity $[5,11]$. In addition, the plant has the unique ability to release oxygen and root exudates into the rhizosphere and the oxygen secreted by the plant roots can be used as an electron acceptor for the CW-MFC to undergo redox reactions $[12,13]$.

Researchers have also carried out studies on water quality parameters; Qian Dandan [14] found that at the optimum glucose concentration of $60 \mathrm{mg} / \mathrm{mL}$, they could obtain the best battery performance with a maximum voltage and power density of $224.8 \mathrm{mV}$ and $505 \mathrm{~mW} / \mathrm{m}^{3}$. Jin Xiaojun [15] studied on the influence of chemical oxygen demand (COD), shown that an anodic denitrifying MFC (MFC-D) exhibited better COD removal capability and power density than MFC without denitrification (MFC-C), and MFC-D obtained the highest coulombic efficiency of electricity generation and anodic denitrification when the value of $\mathrm{COD} / \mathrm{N}$ ratio is about 5:1; Kong Xiaoying [16] studied the effects of different substrates on the electricity production performance of microbial fuel cells. The experiment found that the simpler the substrate, the smaller the

* Corresponding author: liwanghit@126.com 
internal resistance and the higher the output power. However, few reports have been devoted to the study of the ammonia concentration on the performance of the MFC and of the sewage treatment; the purpose of this study is thus to clarify the effect of the ammonia concentrations on the battery performance. Because the addition of ammonia nitrogen affects the electroncapacitating ability of the cathode of CW-MFC, the cathode electrons accumulate in a large amount, which is not conducive to MFC operation. So this experiment studied the COD variation and ammonia removal for wastewater treatment, and evaluated the output voltage output, power density, current density and coulomb efficiency of the battery.

There are many factors that affect the performance, including Substrate concentration, COD concentration, substrate type, etc. In this paper, carbon felts and a copper net have been used as the cathode, bamboo as the wetland plant, allowing to build a single chamber vertical flow of microbial fuel cells. We have determined the optimum ammonia concentration in the substrate for the microbial fuel cell to provide guidance to next research materials.

\section{Materials and methods}

\subsection{Experimental equipment and materials}

The CW-MFC system used in this work is made of plexiglass cylinders with an inner diameter of $19 \mathrm{~cm}$, a total height of $58 \mathrm{~cm}$; Below is the anode part, above is the cathode part, the total volume of the reactor is 14.75 $\mathrm{L}$, the effective storage capacity is $7.1 \mathrm{~L}$, set the sampling port at the bottom $20 \mathrm{~cm}, 30 \mathrm{~cm}, 40 \mathrm{~cm}$, the upper part contains the water outlet; the filling matrix stacks and the electrode materials are: (from the bottom to the top) a $10 \mathrm{~cm}$ thick ceramic, and three repeated cycles of a $5 \mathrm{~cm}$ thick quartz sand layer and a $5 \mathrm{~cm}$ thick activated carbon particles embedded in a carbon felt electrode. Planting rich bamboo in the cathode. The average size of the activated carbon particles is $4 \mathrm{~mm}$, the specific surface area is $900-1000 \mathrm{~m}^{2} / \mathrm{g}$ the ceramic particle size is $3-5$ $\mathrm{mm}$ and the quartz sand particle size is $3-6 \mathrm{~mm}$. Before filling the electrode material, all materials have been washed with water and dilute hydrochloric acid $(1 \mathrm{mmol} / \mathrm{L})$ [17]. From the bottom of the filled barrel there are three anodes and then a cathode: the area of the barrel is $78.5 \mathrm{~cm}^{2}$. Electrode materials are based on carbon felt and copper mesh, combined with a copper wire. The Copper mesh number is 25 , with a $3 \mathrm{~mm}$ diameter copper wires which are connected to an external $1 \mathrm{k} \Omega$ resistor to form a closed circuit. In the reactor, the temperature is controlled at $27 \pm 3^{\circ} \mathrm{C}$. The schematic diagram of the setup is shown in Figure 1. The physical map is shown in Figure 2.

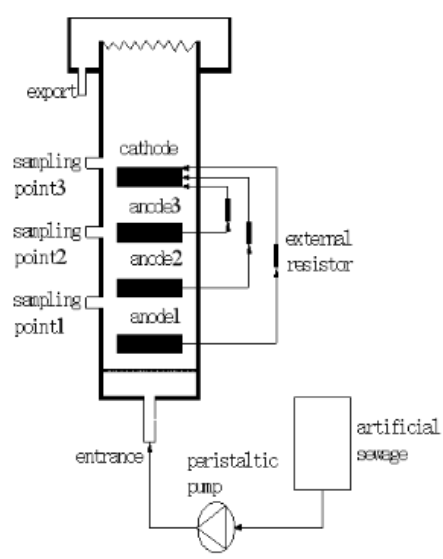

Fig. 1. Schematic diagram of the experimental device

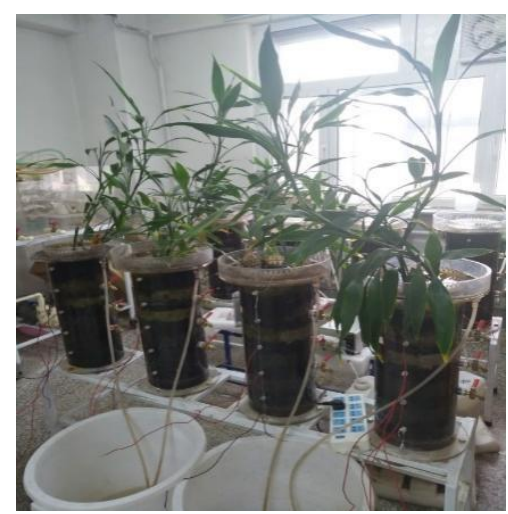

Fig. 2. Physical map of experimental device Carbon felt as the anode and cathode material of the battery, the total surface area

Carbon felt is used as support for both the anode and cathode materials in the battery; the total surface area of the carbon felt is $280 \mathrm{~cm}^{2}$. The seed sludge was taken from the Harbin sewage plant. During the inoculation period, synthetic wastewater was added to support the growth of the microbial communities. In order to ensure the normal operation of the CW-MFC, the anode chamber must be in anaerobic environment: therefore, the anode is fixed at 8,18 and $28 \mathrm{~cm}$ from the bottom of the battery. On the other hand, the cathode chamber must have enough oxygen to ensure that the $\mathrm{H}+$ ions generated at the anode can react with the electrons coming from the external circuit.

Therefore, the cathode is located close to the root of the plant at $48 \mathrm{~cm}$ from the bottom. The plant roots at the cathode allow increasing the oxygen concentration thus enhancing the reaction of the battery. The distance between the cathode and the anodes is 10,20 and $30 \mathrm{~cm}$. The cathode and the anode are connected by an insulated copper wire with a $1 \mathrm{k} \Omega$ resistor. The output voltage is measured every day and recorded. The current and voltage are measured using a digital multimeter.

\subsection{Wastewater treatment and inoculation of the sludge}

The composition of the artificial wastewater at the device starting conditions and during normal operation is shown in Table 1; during the operation the $\mathrm{pH}$ value is adjusted between 7.0 and 7.5 by adding $\mathrm{NaHCO}_{3}$. The 
sewage through the peristaltic pump (BT100M) is continuously delivered to the CW-MFC reactor, from bottom to top, with a water flow of $4.93 \mathrm{~mL} / \mathrm{min}$ and a hydraulic retention time of $24 \mathrm{~h}$. When the system is blocked or the system is backwashed every 6 months, the sludge will be flushed out and the biofilm needs to be reattached, during which there will be biomass loss. The CW-MFC receives the sludge from the Harbin sewage. $1.5 \mathrm{~L}$ of sludge are injected into the reactor for the culture of the system biofilm. For the device filled with water, the water was stopped for 1 day, so that the sludge and the carrier could fully mix.

Table 1. Composition of the synthetic wastewater

\begin{tabular}{ll}
\hline Reagent name & concentration $(\mathrm{mg} / \mathrm{L})$ \\
\hline Glucose & 250 \\
$\mathrm{KNO}_{3}$ & 252.5 \\
$\mathrm{~K}_{2} \mathrm{PO}_{4} \cdot 3 \mathrm{H}_{2} \mathrm{O}$ & 26.32 \\
$\mathrm{NaHCO}_{3}$ & 224 \\
$\mathrm{NaCl}$ & 330 \\
$\left(\mathrm{NH}_{4}\right)_{2} \mathrm{SO}_{4}$ & - \\
$\mathrm{MgSO} 4 \cdot 7 \mathrm{H} 2 \mathrm{O}$ & 0.2 \\
$\mathrm{CaCl} 2$ & 0.015 \\
$\mathrm{FeCl} 3 \cdot 3 \mathrm{H} 2 \mathrm{O}$ & 0.001 \\
$\mathrm{MnSO} 4 \cdot \mathrm{H} 2 \mathrm{O}$ & 0.202 \\
$\mathrm{CoCl} 2 \cdot 6 \mathrm{H} 2 \mathrm{O}$ & 0.0001 \\
$\mathrm{ZnSO} 4 \cdot 7 \mathrm{H} 2 \mathrm{O}$ & 0.00005 \\
\hline
\end{tabular}

\subsection{Testing and calculation methods}

The output voltage $(\mathrm{U})$ is measured with a multimeter. The current (I) in the circuit is calculated by using The Ohm law: the current density, where $\mathrm{V}$ is the effective volume of the anode area within the reaction column. The power output of the reactor is, the power density is, the power density curve is obtained by plotting the power density versus the current density. The polarization curve is measured by the steady-state discharge method, the internal resistance is measured by the power density peak method and the polarization curve method.

The Coulomb efficiency is expressed as follows, $\mathrm{M}$ is the relative molar mass (calculated based on oxygen as the electron acceptor, i.e. $32 \mathrm{~g} / \mathrm{mol}), \mathrm{F}$ is a Faraday constant $(96485 \mathrm{C} / \mathrm{mol}), \mathrm{b}$ is the number of electrons transferred by the oxidation of $1 \mathrm{~mol}$ of organic matter, $\triangle \mathrm{COD}$ is COD change $(\mathrm{g} / \mathrm{L}), \mathrm{V}$ is the effective volume of the anode area of the reaction column $(\mathrm{L}), \mathrm{q}$ is the inlet flow rate $(\mathrm{L} / \mathrm{s})$. The COD was determined by the potassium dichromate oxidation method, and the ammonia nitrogen was determined by the ultraviolet spectrophotometer method of TU-1810 model of Beijing $\mathrm{Pu}$ Analysis General Instrument Co., Ltd. [18].

\section{Results and discussion}

\subsection{Effect of the ammonia concentration on the fuel cell performance}

In this paragraph we investigate the influence of the different kinds of plants, different electrode spacings and different electrode thicknesses on the battery performance. Rich bamboo is used as the wetland plant, the fuel cell electrode spacing is $10 \mathrm{~cm}$, the electrode thickness is $3 \mathrm{~mm}$, study the effect of different ammonia nitrogen concentrations on the electricity production performance of microbial fuel cells. Because $\mathrm{C} / \mathrm{N}$ in the medium has a significant effect on the growth and reproduction of microorganisms and product synthesis. Chen Wei [19] analyzed the effect of carbon-nitrogen ratio on the water quality of the reactor. It was found that the best nitrogen and phosphorus removal effect was obtained when $\mathrm{C} / \mathrm{N}$ was 15 , but the stability of the system was poor. The removal effect of $\mathrm{N}$ is inhibited at high $\mathrm{C} / \mathrm{N}$, but the $\mathrm{C} / \mathrm{N}$ is too low to obtain the effect of nitrogen and phosphorus removal. Therefore, the optimum $\mathrm{C} / \mathrm{N}$ is below 15 and the $\mathrm{C}$ content of this experiment is $132 \mathrm{mg}$, so it is reasonable. The $\mathrm{N}$ content is below $8.8 \mathrm{mg}$, so the ammonia nitrogen content of the selected experiment is $1-30 \mathrm{mg}$. Therefore, the effects of different ammonia nitrogen concentrations of $1,10,20$, and $30 \mathrm{mg} / \mathrm{L}$ on the electricity production performance were investigated. the COD was fixed at $200 \pm 20 \mathrm{mg} / \mathrm{L}$. The ammonia concentration values at the end of production are reported in Fig. 3, showing that when the starting ammonia concentration is $10 \mathrm{mg} / \mathrm{L}$, the maximum output voltage of $550 \mathrm{mV}$ is obtained; at higher ammonia concentration of $30 \mathrm{mg} / \mathrm{L}$, the maximum output voltage of the CW-MFC decreased significantly and at the concentration of $1 \mathrm{mg} / \mathrm{L}, \mathrm{CW}$ MFC output voltage decreases to is only $345 \mathrm{mV}$. Figure 3 shows that ammonia will promote the production of $\mathrm{CW}-\mathrm{MFC}$ at low concentrations, however at too high concentrations it will affect the activity of the CW-MFC microbes, thereby inhibiting their production, which agrees with previous studies from Nam [20]. At low ammonia concentration of $1 \mathrm{mg} / \mathrm{L}$, the voltage generation lowers respect to $10 \mathrm{mg} / \mathrm{L}$, indicating that a such a small concentration, inhibits the activity of anaerobic microorganisms, reducing the electrical performance of the cell.

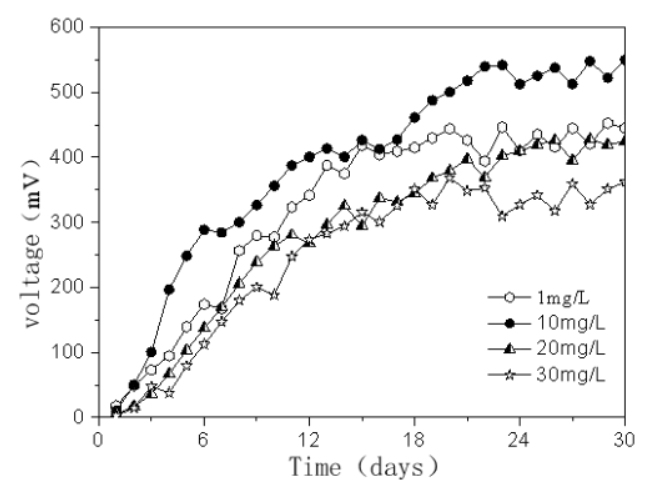

Fig. 3. The battery voltage varies with time at different ammonia nitrogen concentrations

Figure 4 shows the polarization curves and power density curves of the battery under different ammonia concentrations; at the ammonia concentration of 1,10 , 20 and $30 \mathrm{mg} / \mathrm{L}$, the maximum power density is $8.3,13.6$, 6.9 and $2.5 \mathrm{~W} / \mathrm{m}^{3}$, the corresponding current density is 98.9, 148.6, 69.4 and $38.2 \mathrm{~A} / \mathrm{m}^{3}$ and the resulting 
internal resistance is $200,270,300$ and $400 \Omega$, respectively. It can be seen from Figure 3 that the optimum ammonia concentration is $10 \mathrm{mg} / \mathrm{L}$, resulting in a power density which is $1.6,1.9$ and 5.3 times higher respect to what is obtained with of $1,20,30 \mathrm{mg} / \mathrm{L}$ ammonia.

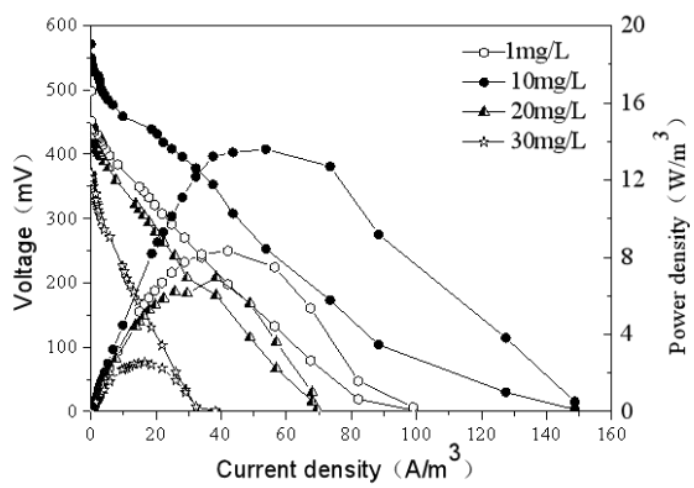

Fig. 4. Polarization curve and power density curve of battery under different ammonia nitrogen concentration

Figure 5 shows the Coulomb efficiency diagrams obtained at different ammonia concentrations. The ammonia concentration results to strongly affect the battery efficiency: at the ammonia concentration of 1,10 , 20 and $30 \mathrm{mg} / \mathrm{L}$ the Coulomb efficiency is $2.5 \%, 3.4 \%$, $2.7 \%$ and $2.4 \%$, respectively. We conclude that the Kurun efficiency of the fuel cell decreases with the increase of the ammonia concentration under certain conditions and the Coulomb efficiency is maximum when the ammonia concentration is $10 \mathrm{mg} / \mathrm{L}$. The possible reason for the efficiency reduction at low ammonia concentration is that by using a carbon felt thickness of $1 \mathrm{~mm}$, the COD removal efficiency is high, and the efficiency of Coulomb is inversely proportional to the variation of the COD, so that the Coulomb efficiency is relatively low.

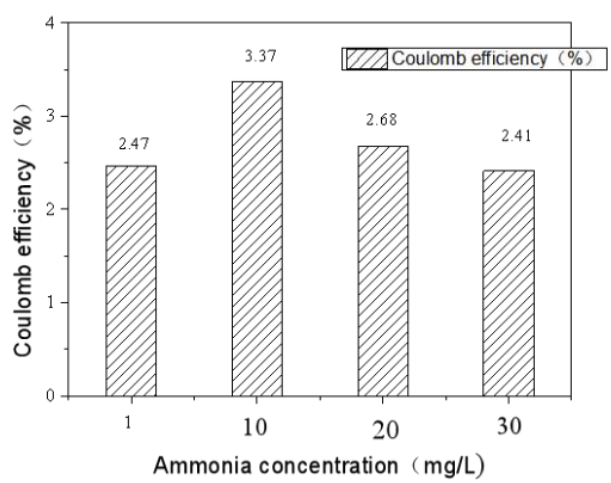

Fig. 5. The coulomb efficiency of battery under different ammonia nitrogen concentration

\subsection{Ammonia removal rate under different ammonia concentrations}

The nitrification and denitrification are two major industrial processes for ammonia treatment [21-23]. The nitrification is the oxidation of $\mathrm{NH}^{4+}$ to $\mathrm{NO}_{2}^{-}$and $\mathrm{NO}_{3}^{-}$, denitrification reaction formula: $\mathrm{NO}_{3}^{-}+\mathrm{C}_{6} \mathrm{H}_{12} \mathrm{O}_{6} \rightarrow$
$\mathrm{N}_{2}+\mathrm{CO}_{2}+\mathrm{H}_{2} \mathrm{O}+\mathrm{OH}^{-}$, so the final $\mathrm{N}$ element is discharged as nitrogen. In the process of ammonia nitrogen nitration and denitrification, $\mathrm{NO}_{2}^{-}$and $\mathrm{NO}_{3}{ }^{-}$will be produced. It can be seen from Table 2 that the $\mathrm{NO}_{2}{ }^{-}$ content is not measured in the whole process, although there is a high content of $\mathrm{NO}_{3}^{-}$because $\mathrm{NO}_{3}{ }^{-}$is present in the configured sewage, but the $\mathrm{NO}_{3}{ }^{-}$content decreases with time and is lower than the $\mathrm{NO}_{3}{ }^{-}$at the inlet. The content is so good that the denitrification process works well. The removal rate of ammonia is strongly related to the amount of oxygen in the system, since oxygen is required to support the growth of nitrifying bacteria. According to Grady [24], nitrification may also occur at low levels of DO, however, the response rate is significantly reduced compared to DO levels higher than $2 \mathrm{mg} / \mathrm{L}$. In this experiment, the DO content at the outlet was about $4 \mathrm{mg} / \mathrm{L}$, the anaerobic zone of the cell was at the bottom of the cell (near the anode), and the aerobic zone was at the top of the cell root (cathode zone).

Table 2. Composition of the $\mathrm{NO}_{3}{ }^{+}-\mathrm{N} 、 \mathrm{NO}_{2}-\mathrm{N}$

\begin{tabular}{|c|c|c|}
\hline & Time & $\begin{array}{l}\text { Effluent concentration } \\
(\mathrm{mg} / \mathrm{L})\end{array}$ \\
\hline \multirow[t]{4}{*}{$\mathrm{NO}_{3}{ }^{+}-\mathrm{N}$} & $\begin{array}{l}15 \text { days from the } \\
\text { start }\end{array}$ & $270-289$ \\
\hline & First month & $240-255$ \\
\hline & Second month & $233-245$ \\
\hline & Third month & $188-186$ \\
\hline $\mathrm{NO}_{2}^{-}-\mathrm{N}$ & All time & Null \\
\hline
\end{tabular}

In order to study the effect of the ammonia concentration on a single chamber $\mathrm{CW}-\mathrm{MFC}$, we have placed the initial external resistance of $1 \mathrm{k} \Omega$, and explored different ammonia concentrations of 1, 10, 20 and $30 \mathrm{mg} / \mathrm{L}$. The concentration of ammonia in the battery outlet was measured with a spectrophotometer to deduce the ammonia removal rate as shown in Figure 6.

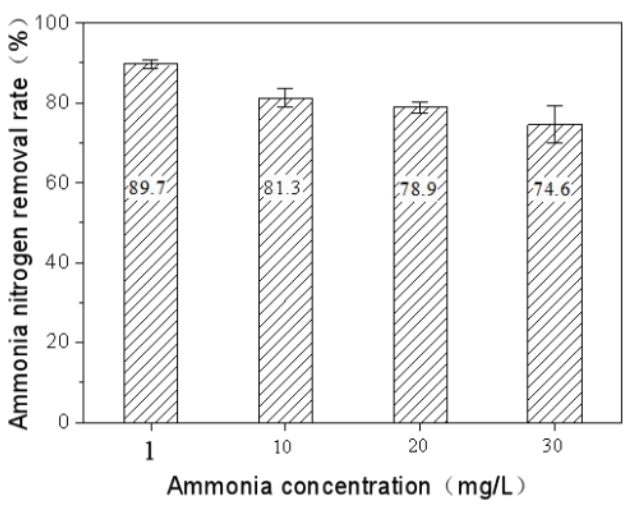

Fig. 6. Removal rate of ammonia nitrogen under different ammonia nitrogen concentration

From the Fig. 6, for the inlet concentration of 1, 10, 20 and $30 \mathrm{mg} / \mathrm{L}$ the removal rate of ammonia results $89.7 \%, 81.3 \%, 78.9 \%$ and $74.6 \%$ respectively. The higher is the ammonia concentration, the lower is the removal rate. This is because the nitrification process relies on the oxygen content. When the oxygen content is constant, the ammonia nitrogen removal amount is constant, so as the ammonia nitrogen concentration increases, the removal rate decreases. It is also possible 
that the ammonia nitrogen concentration is too high and the activity of the microorganism is suppressed. This suggests that when the dissolved oxygen in the cathode chamber cannot be controlled, an appropriate amount of ammonia has to be introduced to avoid that the dissolved oxygen impacts on the denitrification yield at the CWMFC cathode, while for optimizing the nitrification and denitrification at the same time in a single reaction chamber, the cathode itself has to produce enough electrons for the denitrification, and to achieve a balance between the nitrification and denitrification, one should avoid the remaining dissolved oxygen to affect the cathodic indoor denitrification, while the denitrification should be kept sufficiently strong to provide the anode needs in electrons, so that a high electrons current flow through the external circuit; this will be the next step in our research objectives.

\subsection{COD removal rate at different ammonia concentrations}

In order to study the effect of the ammonia concentration on the COD removal rate of a single-chamber CW-MFC, we applied an initial external resistance of $1 \mathrm{k} \Omega$, and varied the ammonia concentration from 1, 10, 20 and 30 $\mathrm{mg} / \mathrm{L}$. The outlet COD concentration in the battery is measured by the potassium dichromate method to finally calculate the COD removal rate; the results are shown in Figure 7.

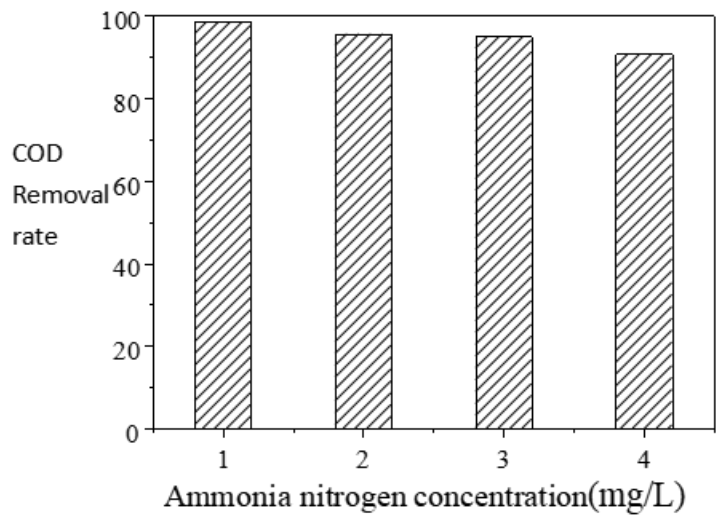

Fig. 7. COD removal rate at different ammonia nitrogen concentration

It can be seen from Fig. 7 that at 1, 10, 20 and 30 $\mathrm{mg} / \mathrm{L}$ ammonia, the corresponding COD removal rates are $98.5 \%, 95.6 \%, 94.5 \%$ and $90.7 \%$, respectively. The higher is the ammonia nitrogen concentration at the inlet, the lower is the removal rate; this is ascribed to the fact that a too high ammonia content results in the sludge denitrification, which can cause the activated sludge to float, and thus lowering the microbial population in the activated sludge, thereby reducing the COD removal efficiency.

\section{Conclusions}

In this paper, we mainly studied the effects of the ammonia concentrations on the electricity generation performance and wastewater treatment performance of a microbial fuel cell; the following conclusions apply:

(1) The ammonia promotes the efficiency of the CWMFC at low concentrations. However, above a certain concentration the ammonia will lower the activity of CW-MFC microbes, thereby inhibiting the energy production of the cell. When the ammonia concentration is $1 \mathrm{mg} / \mathrm{L}$, the voltage generation is suppressed; this is due to the fact that at too low ammonia concentration the anaerobic activity microorganisms is inhibited, which reduces the electricity generation performance.

(2) The ammonia concentration affects the power density delivered from the battery; at the ammonia concentration of $1,10,20$ and $30 \mathrm{mg} / \mathrm{L}$, the maximum power density is $8.3,13.6,6.9$ and $2.5 \mathrm{~W} / \mathrm{m}^{3}$, corresponding to the current density of $8.9,148.6,69.4$ and $38.2 \mathrm{~A} / \mathrm{m}^{3}$, and the calculated internal resistance of $200,270,300,400 \Omega$ respectively. When the ammonia concentration is $10 \mathrm{mg} / \mathrm{L}$, the battery provides for the best performance, with a power density 1.6, 1.9 and 5.3 times higher respect of 1,20 and $30 \mathrm{mg} / \mathrm{L}$.

(3) The removal rate for the inlet ammonia concentration 1, 10, 20 and $30 \mathrm{mg} / \mathrm{L}$ is $89.7 \%, 81.3 \%$, $78.9 \%$ and $74.6 \%$ respectively, thus the higher is the ammonia nitrogen concentration, the lower is the removal rate.

(4) When the inlet ammonia concentration is 1,10 , 20 and $30 \mathrm{mg} / \mathrm{L}$, the corresponding COD removal rates are $98.5 \%, 95.6 \%, 94.5 \%$ and $90.7 \%$ respectively, thus the higher is the ammonia concentration, the lower the COD removal rate.

\section{References}

[1] L. Doherty, XH Zhao, YQ Zhao, WK Wang. Ecol. Eng.79.8-14(2015)

[2] R.A. Timmers, D.P.B.T.B. Strik, H.V.M. Hamelers, C.J.N. Buisman. Appl. Microbiol. Biotechnol. 86.973-981(2010)

[3] K. Wetser, E. Sudirjo, C.J.N. Buisman, D.P.B.T.B. Strik. Appl. Energy.137.151-157(2015)

[4] M. Helder, D.P.B.T.B. Strik, H.V.M. Hamelers, A.J. Kuhn, C. Blok, C.J.N. Buisman. Bioresour. Technol.101.3541-3547(2010)

[5] N. Kahu, N.Yonezawa, Y. Kodama, K. Watanabe. Appl. Microbiol. Biotechnol.79.43-49(2008)

[6] A. Al-Mamun, O. Lefebvre, M.S. Baawain, H.Y. Ng. Int. J. Environ. Sci. Technol. 13.10551064(2016)

[7] E.M. Milner, D. Popescu, T. Curtis, I.M. Head, K. Scott, E.H. Yu. J. Power Sources.324.8-16(2016)

[8] V. Srinivasan, J.Weinrich, C. Butler. Environ. Sci.Wat. Res. Technol.2.344-352(2016)

[9] P. Clauwaert, D. Van der Ha, N. Boon, K. Verbeken, M. Verhaege, K. Rabaey, W. Verstraete. Environ. Sci. Technol.41.7564-7569(2007)

[10] Z He, L.T. Angenent. Electroanalysis.18.20092015(2006)

[11] P. Chiranjeevi, G. Mohanakrishna, SV. Mohan. Bioresour. Technol. 124.364-370(2012) 
[12] ZC Chen, X Chen, P Liu, DF Huang, HJ Liu.BMC Neurosci.13.55(2012)

[13] YF Chen, ZS Lv, JM Xu, DQ Peng, YX Liu, JX Chen, XB Sun, CH Feng, CH When. J. Power Sources.201.136-141(2012)

[14] DD Zhou, CY Jian. Environ. Eng. (in Chinese)10.2725-2732

[15] XJ Jin, F Guo, WQ Ma, Y Liu, H Liu. Chem. Eng. J.370.527-535(2019)

[16] XY Kong, YM Sun, LH Li. Transactions of the CSAE. (in Chinese).27.185-188(2011)

[17] J.W. Zhang, E.R. Zhang, K. Scott, J.G. Burgess. Environ. Sci. Technol.46.2984-2992(2012)

[18] XN Li, HL Song, WL Xiang. J. of SEU. (in Chinese)28.175-178(2012)

[19] W Chen, HX Tan, GZ Luo, DC Sun, WC Liu. Journal of SHOU. (in Chinese).27.907-915(2018)

[20] J.Y. Nam, H.M. Kim, H.S. Shin. J. Power Sources. 195.6428-6433(2010)

[21] S.A. Ong, K. Uchiyama, D. Inadama, Y. Ishida, K. Yamagiwa. Bioresour. Technol.101.7239-7244 (2010)

[22] M.M. Ghangrekar, V.B. Shinde. Bioresour. Technol. 98.2879-2885(2006)

[23] B.Virdis, K. Rabaey, R.A. Rozendal, ZG Yuan, J. Keller. Water Res.44. 2970-2980(2010)

[24] C.P. Grady, L.Lim, C. Henry. (1980) Biological Wastewater Treatment: Theory and Applications. 